\section{BOTANICAL SEMINAR OF THE UNIVERSITY} OF NEBRASKA.

AT the regular meeting on November 1, Dr. Roscoe Pound read a paper on 'The Purpose and Force of Botanical Laws,' directing attention to the fact that rules of procedure in science are as necessary as they are in civil life, and indicating that the method by which laws are obtained in the one case must be similar to those in the other. The paper was discussed by Professor Bessey (who spoke of the supposed danger of a repression of originality through the action of laws of science); Dr. Wolcott (who called attention to the code of laws and their successful execution in ornithology); and Dr. Clements (who discussed a proposed series of regulations in regard to the nomenclature of plant geography).

\section{DISCUSSION AND CORRESPONDENCE.}

PREgLACIAL DRAINAGE IN SOUTHWESTERN OHIO.

To The Editor of ScIEnce: In the issue of Science of October 4, Professor Arthur M. Miller offers an objection to the conclusions of Mr. Fowke, 'made from his studies on the drainage features of southwestern Ohio, in which Mr. Fowke has shown (Bulletin of the Scientific Laboratories of Denison University and Special Paper No. 3 of the Ohio State Academy of Science) that the preglacial drainage of the section of the Ohio river from Manchester, Ohio, to Madison, Ind., was to the northward along the line of the lower Big Miami and the Mill creek valleys to Hamilton. It has been my pleasure to have studied somewhat carefully the region under discussion in my field work, and the objections which seem so apparent to Professor Miller have not appeared so to me. While I would agree in the main with Professor Miller in his argument concerning the formation of reentrants made by up-stream cut. ting against an escarpment and the stratigraphic relations of stream gradient and dip, under which similar reentrants would be formed by streams flowing in the direction of the dip, I cannot see that there is much force in the application of these principles to the problem under discussion. There is no question but that many of the reentrants found in the Clinton limestone outcrop of the region shown by Professor Miller's map were made in the manner he suggests. I have observed many of them in the field. But at the same time there are many possibilities of there being, in this same region, large valleys deeply buried under the mantle of drift running in the opposite direction from that of these reentrants which were formed by the backward-cutting streams. In all cases which I have observed of these reentrants made by backward-cutting streams, they might have as well formed part of a system of lateral tributaries to a main northward-flowing stream as to that of a southward-flowing one. Unfortunately the region which Professor Miller has chosen in his map and studies is not the same as that which furnished the data for the determination of the northward direction of the preglacial waters from the vicinity of Cincinnati and it would be hardly necessary to review these data at this time, as the full reports are easily accessible in the articles referred to and are not discussed by Professor Miller. It may be well to state, however, that the criteria used in the location of the preglacial lines of drainage are not confined to a study of comparative 'widthof-channel' of streams, but the conclusions are based upon a broader study of topographic forms, comparative erosion, distribution and direction of shingling of old gravels on the old graded valley floors, normal and abnormal stream relations and many other similar lines of evidence.

In Professor Miller's closing paragraph he speaks of the symmetry shown by the streams north and south of the Ohio river as adding force to the argument in favor of the present arrangement of the streams being also the preglacial arrangement, and he considers the Ohio as the main and parent stream. There seems to be an abundance of evidence, already published, to show that in preglacial times a strong watershed crossed the Ohio river near Manchester, Ohio, and that the section of the Ohio immediately above Manchester found its way up the reversed Scioto in preglacial times. With the Ohio river above Cincinnati reduced to a small stream (which Mr. Fowke calls Old Limestone) heading only at Manchester, it 